\title{
DESAIN MONETARY POLICY RULE UNTUK PEREKONOMIAN TERBUKA: KASUS INDONESIA
}

\author{
G. Sudjana Budhiasa \\ Fakultas Ekonomi Universitas Udayana Bali
}

\begin{abstract}
This paper is trying developing a small scale Keynesian macroeconometric model for Indonesia as the main framework to explain some characterized of macroeconomic variables and its transmission path in order to understand how economy of one country is work. However, the main goal of the developing this macroeconomic model is based on monetary perspective, so that the model would be linked with policy framework of Central Bank as guidance and its strategy for combating inflation and at the same time can be achieve the expansion of employment and economic growth as well. This macroeconometric model is transmitted facilities and take function as the macroeconomic channel for testing the effectively of BI rate as monetary instrument. So that the model as developed in this paper will be examine using $2 S L S$ simultaneous econometric methods and the next simulation process as an effort in understanding the fenomena as Indonesian economy is working under the recognition of monetary instrument policy.
\end{abstract}

Kata Kunci: Monetary policy rule, opened policy rule, output gap.

Kebijakan moneter Bank Sentral sebelum krisis mempergunakan piranti uang primer sebagai jangkar kebijakan moneter untuk mencapai stabilitas inflasi, pertumbuhan ekonomi, serta stabilitas neraca pembayaran. Fakta menunjukkan bahwa penggunaan jangkar uang primer seringkali tidak sejalan dengan sasaran akhir pencapaian suku bunga perbankan yang diharapkan, sehingga tujuan akhir yang ingin dicapai dari pengelolaan uang primer tersebut tidak sepenuhnya dapat mencapai sasaran pembentukan nilai suku bunga yang diinginkan.

Kebijakan moneter Bank Sentral setelah krisis telah menetapkan upaya pencapaian satu target yaitu stabilitas perekonomian nasional, dengan mempergunakan jangkar suku bunga sebagai instrument moneter. Studi ini mencoba merumuskan sebuah formulasi kebijakan moneter yang berbasis kepada policy rule, yaitu kebijakan menetapkan suku bunga yang dilaksanakan berdasarkan formulasi deviasi output, deviasi inflasi serta pergerakan kurs tukar. Formulasi kebijakan policy 
rule pertama kali direkomendasikan oleh John Taylor (1993), yang didukung oleh management pengelolaan inflation targeting framework.

McNeal (1999) merekomendasikan kepada Bank Indoinesia untuk menerapkan Taylor rule yang lebih memberi prioritas kepada pertumbuhan ekonomi. Darsonoi (2002) merumuskan policy rule yang tidak berbeda dengan MacNeal, tetapi dengan pembobotan yang lebih memberi priotritas kepada tujuan tunggal inflasi, dengan mengabaikan target pertumbuhan ekonomi.

Paper ini mengajukan pemodelan policy rule yang diharapkan lebih realistic, dengan merumuskan policy rule yang sejalan dengan kebutuhan dimana perekonomian Indonesia bersifat terbuka. MacNeal (1999) maupun Darsono et al (20002) mengembangkan policy rule untuk perekonomian tertutup, sehingga rekomendasi kebijakan besaran suku bunga yang diatur melalui mekanisme BI rate dapat menghasilkan rekomendasi yang bias, mengingat adanya fakta dalam perekonomian terbuka yaitu bahwa pergerakan inflasi juga dapat disebabkan oleh arah perubahan sektor eksternal peerdagangan internasional.

Dalam rangka menemukan policy rule yang relevan dan realistis untuk perekonomian Indonesia, tulisan ini mengembangkan model makro berskala kecil sebagai mekanisme transmisi untuk menguji efektivitas kebijakan moneter yang berbasis policy rule dengan penggunaan instrument suku bunga sebagai pilihan jangkar kebijakan moneter menggantikan jangkar uang primer yang dipergunakan sebelum kebijakan inflation targeting diberlakukan.

Dalam rangka menelusuri efektivitas kebijakan moneter berbasis policy rule, tulisan ini melakukan tiga tahapan kegiatan. Tahap pertama, penelitian melakukan penelusuran teori, penetapan kerangka pikir serta penterjemahan kerangka pikir menjadi pemodelan kuantitatif ekonometrik. Dalam penelusuran teori, diberlakukan asumsi bahwa perekonomian Indonesia bersifat terbuka yang memiliki karakter pergerakan modal internasioanl sempurna. Asumsi berikutnya, adalah bahwa public memiliki informasi yang cukup dan mempergunakan informasi yang mereka miiliki secara optimal.

Tahap kedua, adalah menyediakan metode ekonometrik simultan yang sebelumnya telah disusun spesifikasinya melalui kerangka pikir maupun turunan pemodelannya menjadi model makro ekonomi kuantitatif. Metode ekonometrik yang dipakai adalah metode simultan 2SLS. Melalui prosedur regressi dua tahap, penelitian melakukan pengelompokkan variable ke dalam sistem persamaan struktural, yang 
terdiri dari pengelompokkan ke dalam persamaan endogen dan persamaan eksogen. Hasil analisis yang diharapkan diperoleh dari penggunaan moderl simultan dua tahap adalah bahwa pada tahap pertama, penelitian melakukan penelusuran kinerja sejumlah variable dalam kelompok reduced form, yang pada gilirannya akan memberi pengaruh akhir pada persamaan endogen yang dimuat pada persamaan struktural, sehingga memberi kemungkinan diperolehnya outcome dari peranan policy rule suku bunga sebagai jangkar kebijakan moneter dalam mempengaruhi kinerja perekonomian nasional.

Tahap ketiga, adalah simulasi yang dilakukan berdasarkan simulasi dalam sample dan simulasi diluar sample. Simulasi yang dilakukan dalam data sampel dimaksudkan untuk mendapatkan informasi kemampuan model dalam melakukan prediksi. Sedangkan simulasi diluar sample dimaksudkan untuk mendapatkan gambaran efektivitas dari penggunaan policy variable kebijakan moneter suku bunga terhadap sistem keseimbangan, dalam rangka mendapatkan hasil akhir kebijakan moneter yaitu stabilitas inflasi dan pertumbuhan ekonomi.

Kebijakan moneter inflation targeting framework (ITF) di Indonesia sejalan dengan ketentuan perundangan yang diatur pada UU No. 25 tahun 1999, yang pada intinya menugaskan Bank Sentral untuk menciptakan stabilitas perekonomian nasional. Mengikuti Mishkin dan Beranke (1999), inflation targeting adalah strategi kebijakan moneter, sedangkan policy rule adalah otomatisasi yang ditentukan berdasarkan pergerakan dinamik dari sejumlah variable makro ekonomi.

John B. Taylor (1993) merumuskan policy rule berdasarkan penggunaan jangkar suku bunga sebagai instrument moneter yang besarannya ditentukan berdasarkan perkembangan dinamis dari deviasi output gap dan deviasi inflasi. Di Indonesia, kebijakan penerapan policy rule dengan penggunaan jangkar moneter suku bunga didukung oleh pola pengendalian inflation targeting framework.

Svensson (2000), merumuskan inflation targeting framework sebagai komponen yang memiliki paling sedikit 5 ketentuan antara lain, pertama, adanya kewajiban Bank Sentral untuk mengunumkan perencanaan target pencapaian inflasi dalam setiap awal tahun anggaran. Kedua, Bank Sentral adalah independent dalam proses pengambilan keputusan. Ketiga, Bank Sentral wajib menyampaikan instrument moneter yang dipergunakan dan cara mencapainya. Keempat, Bank Sentral memiliki management yang terbuka. Kelima, Bank Sentral melakukan kebijakan secara transparan dan accountable yang dapat di akses publik setiap saat diperlukan. 
Penelitian ini berusaha merumuskan policy rule yang lebih realistis untuk perekonomian Indonesia. Pertama, perumusan policy rule disusun dengan menyertakan variable nilai tukar, sehingga diharapkan penetapan suku bunga BI rate bisa didapatkan dengan meilihat dinamika sektor eksternal. Kedua, penelitian berusaha menyertakan prilaku publik yang antisifatif, yaitu pemanfaatan informasi yang diperoleh tahun berjalan sebagai sarana dalam pengambilan keputusan.

\section{Monetary Policy Rule: Perspektif Teori}

Pemodelan disusun untuk menjawab permasalahan penelitian yaitu untuk mendapatkan policy rule yang lebih realistis bagi perekonomian Indonesia. Untuk mendapatkan policy rule untuk perekonomian Indonesia, penelitian mengadopsi policy rule dari Taylor (1993) dengan sistem persamaan sebagai berikut.

$$
i_{t}^{*}=4+1.5\left(\pi_{t}-2\right)+0.5\left(y_{t}-y_{t}^{*}\right)
$$

Berdasarkan policy rule sebagaimana digambarkan persamaan (1.1) tampak bahwa penentuan suku bunga $\left(i^{*}\right)$ tidak dilaksanakan secara discretion, tetapi berdasarkan rule yang ditentukan oleh dinamika inflasi dan output gap. Berdasarkan teori yang tersedia, bahwa apabila Bank Sentral bertugas untuk mengendalikan inflasi, maka hal demikian dapat dilakukan dengan penggunaan instrumen suku bunga. Pengaruh perubahan suku bunga tidak secara langsung menentukan perubahan inflasi, tetapi secara tidak langsung melalui sejumlah proses transmisi dari perubahan suku bunga yang berdampak pada sejumlah variable ekonomi makro lainnya, termasuk pertumbuhan output riel dan neraca pembayaran.

Taylor rule sebagaimana diuraikan pada persamaan (1.1) adalah policy rule untuk perekonomian tertutup. Sejumlah modifikasi telah dilakukan antara lain oleh Svensson (1998), Batini dan Haldane (1999), Clarida et al (2000), dan Woodford (2001). Sejumlah modifikasi dimaksud adalah upaya pengembangan Taylor rule menjadi policy rule untuk perekonomian terbuka yaitu dengan menyertakan variabel nilai tukar, sehingga sasaran akhir pengendalian inflasi dan atau pertumbuhan ekonomi yang direncanakan untuk dicapai telah dilakukan melalui pertimbangan yang sejalan dengan dinamika perekonomian terbuka.

Dalam melihat tahapan proses transmisi pengaruh dari perubahan suku bunga terhadap perekonomian nasional, pendekatan yang dipergunakan adalah pemodelan 
dari varitas Keynesian yang dirintis oleh Mundell-Fleming dari IMF (1962) yang memandang bahwa pada perekonomian negara kecil, lalu lintas modal internasional memiliki karakter pergerakan sempurna di mana negara kecil terposisikan sebagai negara yang tidak memiliki kekuatan yang cukup untuk mempengaruhi pasar keuangan (price taker).

Dalam memahami efektivitas instrumen suku bunga sebagai jangkar kebijakan moneter, diperlukan penguraian transmisi yang memuat hubungan antar variable makro ekonomi. Dalam rangka memahami framework pemodelan Mundell-fleming dan arah perkembangan Keynesian theoretical framework, bagain 1.1 menyajikan model transmisi yang memuat kerangka hubungan antar variable makro ekonomi yang berbasis pada agregate demand sebagaimana menjadi karakter yang mewakili teoritisi Keynesian dalam pembentukan keseimbangan ekonomi jangka pendek.

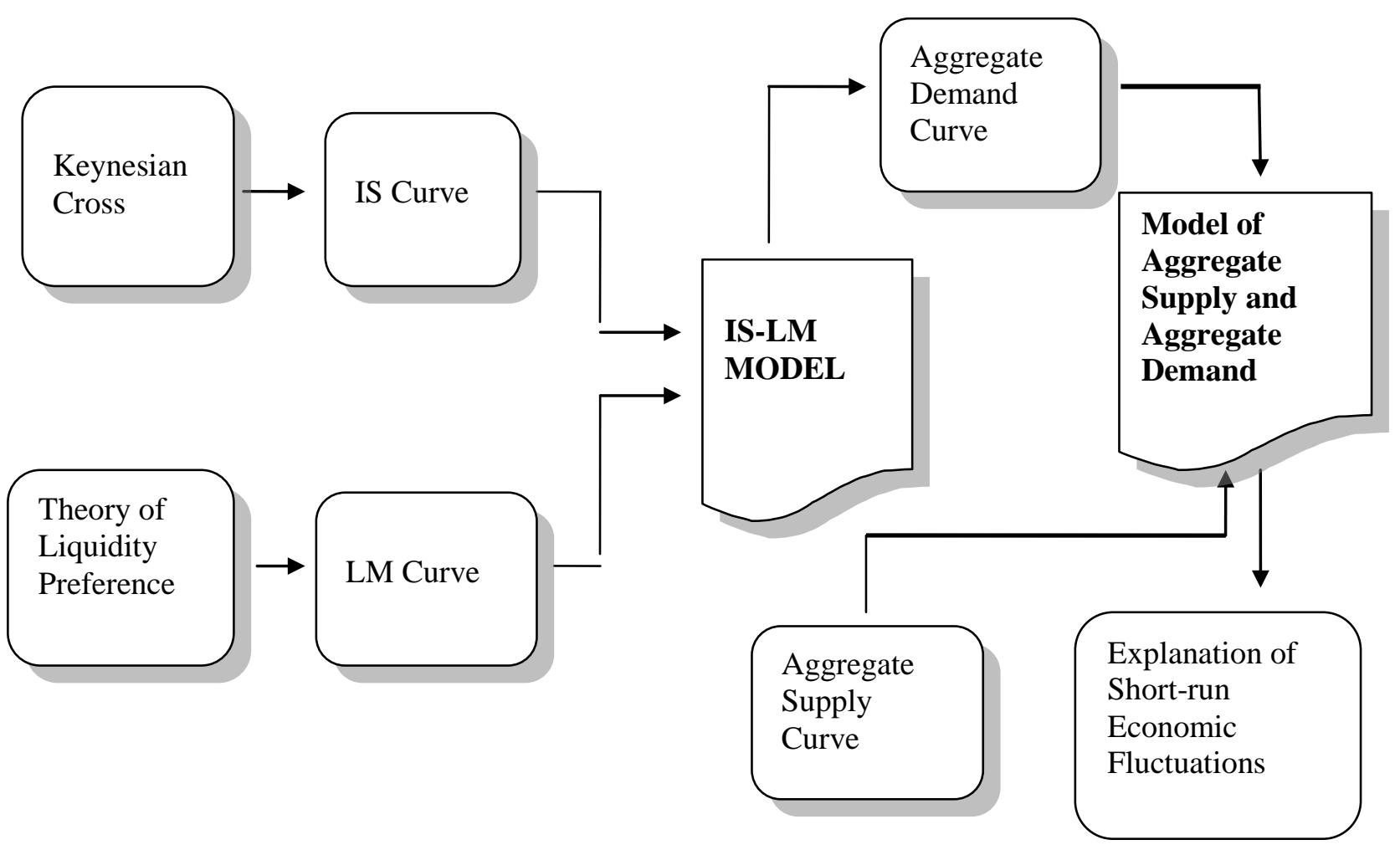

Sumber : Mankiw, 2002. 
Bagan 1.1 menyajikan mekanisme transmisi perekonomian makro yang memuat sisi fiskal (Keynesian Cross) dan sisi liquidity preference yang membentuk pasar uang (LM). Interaksi dari dinamika fiskal yang membentuk dinamika pasar barang (IS Curve) dan pasar uang (LM Curve) akan menuju pada proses pembentukan keseimbangan berikutnya yaitu keseimbangan pasar barang dan pasar uang ( IS-LM Model ). Dengan demikian, pembentukan model IS-LM yang bersumber dari pasar barang maupun pasar uang, keduanya akan bergerak menuju dinamika prilaku agregate demand sebagai penggerak terbentuknya sasaran akhir pertumbuhan produksi dan perluasan lapangan kerja.

Tradisi Keynesian selalu mempergunakan dinamika agregate demand sebagai policy variable dalam menggerakkan keseimbangan jangka pendek, termasuk upaya untuk menyelesaikan trade-off pertumbuhan output dan pengendalian inflasi. Dengan mempergunakan piranti suku bunga sebagai jangkar kebijakan moneter, sasaran akhir kebijakan moneter seperti pengendalian inflasi yang lebih rendah dan stabil dengan ruang gerak pertumbuhan ekonomni yang memadai diharapkan dapat dicapai. Dengan menyimak kembali bagan 1.1, maka proses terbentuknya keseimbangan jangka pendek adalah terbentuknya poses keseimbangan agregate demand dan agregate supply. Dengan demikian, kerangka teori Keynesian memiliki karakter di mana agregate supply (AS) adalah pasif.

Dalam sebuah perekonomian terbuka, sistem keseimbangan masih dapat diperluas dengan menyertakan foreign exchange market, yaitu pasar uang internasional yang berinteraksi sebagai akibat dari proses perdagangan antar bangsa. Semakin besar cakupan dan luas transaksi perdagangan internasional antara penduduk satu negara dengan bangsa-bangsa lain, maka semakin berkembang dan komplek permasalahan nilai tukar dengan aneka ragam pengaruhnya terhadap perekonomian Indonesia. Pemodelan disusun berdasarkan Keynesian theoretical framework yang memiliki karakter jangka pendek, yang memiliki 3 sistem persamaan dominan yaitu pasar barang (IS), pasar uang (LM) serta pasar valuta asing (FE). Disusun dalam bentuk hubungan transmisi, pemodelan makro ekonomi berskala kecil diuraikan pada bagan 1.2..

\author{
Bagan 1.2 : \\ Mekanisme Transmisi Model Ekonomi Makro Indonesia
}




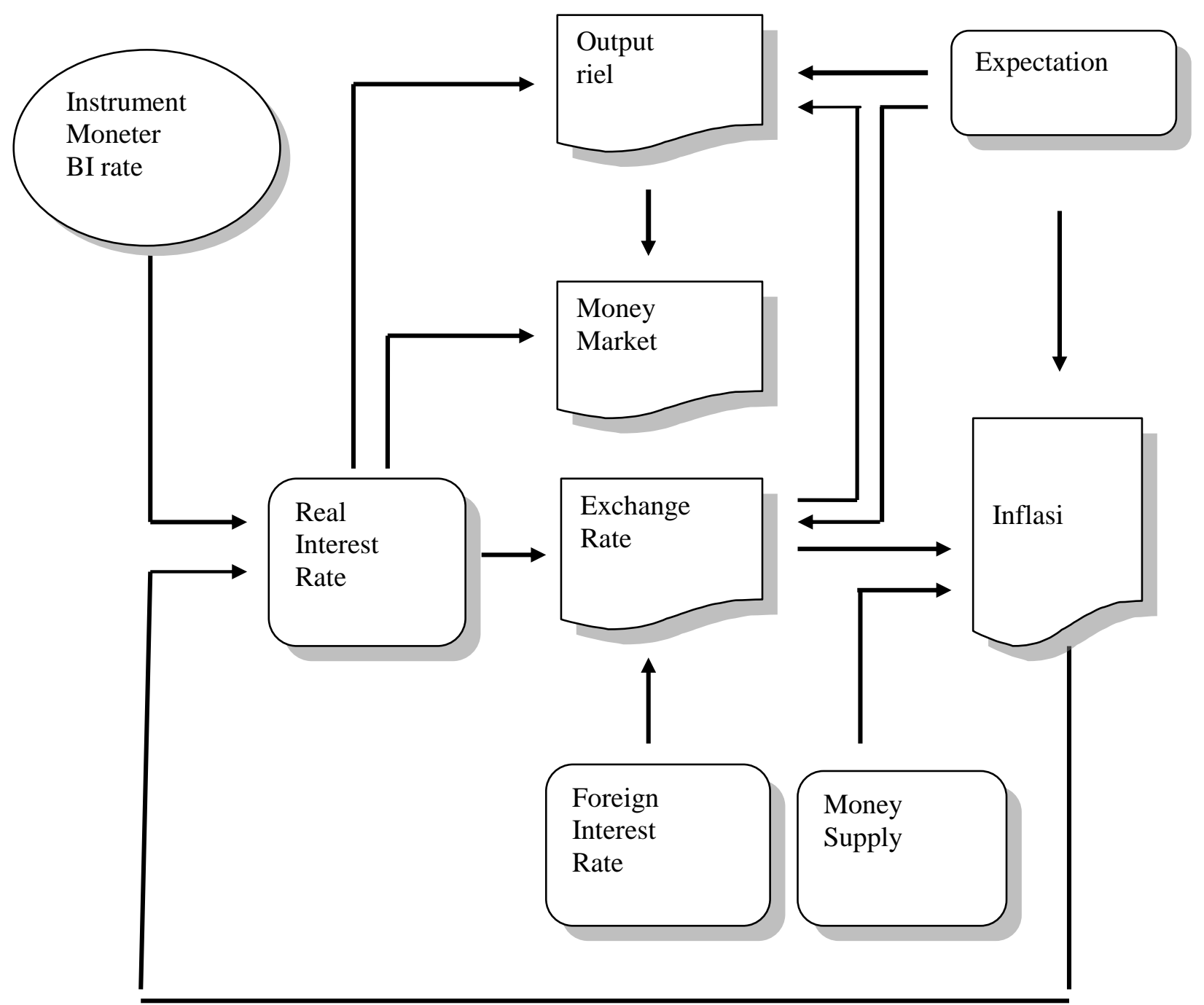

Penguraian model transmisi dijabarkan dalam bentuk kuantitatif ekonometrik untuk menetapkan dan mendapatkan gambaran hubungan antar variable makro ekonomi, sehingga keterkaitan antara satu variable dengan variable lainnya dapat ditingkatkan menjadi spesifikasi model (model specification), sekaligus dapat ditelusuri lebih jauh pengembangan data sample untuk mendapatkan justifikasi model yang menghubungan antara pendekatan teori dan fakta yang terjadi di dunia nyata. Rumusan pemodelan transmisi makro ekonomi yang dimuat pada bagan 1.2 dijabarkan menjadi sistem persamaan adalah sebagai berikut. .

\section{Pasar Barang}

$$
y_{t}=\alpha_{1}+\beta_{1} y_{t-1}+\beta_{2} y_{t+1}+\beta_{3}\left(i_{t-1}-\pi_{t-1}\right)+\beta_{4} q_{t-1}+\varepsilon^{y}
$$

\section{Persamaan Inflasi :}

$$
\pi_{t}=\alpha_{2}+\beta_{5} \pi_{t+1}+\beta_{6} \pi_{t-1}+\beta_{7} m s x_{t}+\beta_{8} k u r s_{t}+\varepsilon^{\pi_{t}}
$$




\section{Pasar Uang}

$$
m_{t}-p_{t}=\alpha_{3}+\beta_{9} y_{t}-\beta_{10}\left(i_{t-1}-\pi_{t-1}\right)+\varepsilon^{m-p}
$$

\section{Pasar Valuta Asing Dan Aliran Modal Internasional}

$$
q_{t}=\alpha_{4}+\beta_{11} q_{t+1}+\beta_{12} q_{t-1}-\beta_{13}\left(i_{t-1}+\pi_{t-1}\right) / i_{t-1}^{f}+\varepsilon^{e}
$$

\section{Policy Rule :}

$i_{(3 . \overline{5)}} \lambda_{1} \pi_{t+1}+\lambda_{2}\left(y_{t}-y_{t}^{*}\right)+\lambda_{3}\left(\pi_{t}-\pi_{t}^{*}\right)-\lambda_{4} q_{t}+\varepsilon^{i_{t}}$

Persamaan (3.1) sampai dengan (3.4) adalah model makro ekonomi yang diturunkan dari bagan 1.2, sedangkan persamaan (3.5) adalah policy rule, yaitu rule yang akan menghasilkan penetapan suku bunga. Berdasarkan penetapan suku bunga tersebut, kemudian dilakukan justifikasi untuk mendapatkan jawaban dampak dari penatapan suku bunga terhadap perekonomian nasional.

Persamaan (3.1) sampai dengan persamaan (3.5) adalah model persamaan makro yang tidak dapat dillepaskan kaitannya antara satu dengan lainnya, sehingga dapat dinyatakan sebagai bentuk persamaan simultan. Jika demiikian maka persamaan (3.1) sampai dengan (3.5) adalah persamaan struktural yang dikelompokkan menjadi persamaan endogen dan persamaan eksogen. Persamaan endogen adalah persamaan di mana variabel. makro ekonomi berposisi sebagai dependent variable, serta variable independent yang ditempatkan sebagai reduced form pada persamaan struktural. Yang dimaksud dengan reduced form adalah seluruh variable ekonomi makro yang memiliki karakter eksogen. Pengelompokkan variabel ekonomi makro yang termasuk pada persamaan endogen dan eksogen dapat dilihat rinciannya pada Tabel 1.1

Tabel 1.1 :

Pengelompokan Persamaan Struktural Makro Ekonomi 


\begin{tabular}{|l|l|l|l|}
\hline 1 & $\mathrm{yt}$ & Ouput riel produk domestic bruto & Endogin \\
\hline 2 & $\mathrm{yt}-1$ & Output riel satu periode sebelumnya & Eksogen \\
\hline 3 & $\mathrm{yt}+1$ & Output riel satu periode kedepan & Eksogen \\
\hline 4 & $\left(\mathrm{i}_{\mathrm{t}-1}-\pi_{\mathrm{t}-1)}\right.$ & Suku bunga riel satu periode sebelumnya & Eksogen \\
\hline 5 & $\mathrm{qt}$ & Nilai tukar nominal (Rupiah/US \$) & Endogen \\
\hline 6 & $\pi_{\mathrm{t}}$ & Inflasi CPI yoy & Endogen \\
\hline 7 & $\pi_{\mathrm{t}+1}$ & Inflasi CPI yoy satu periode sebelumnya & Eksogen \\
\hline 8 & $\pi_{\mathrm{t}-1}$ & Inflasi CPI yoy satu periode kedepan & Eksogen \\
\hline 9 & $\mathrm{msx}$ & Jumlah uang beredar (M1) & Eksogen \\
\hline 10 & $\mathrm{qt}$ & Permintaan valuta asing (US \$) & Endogen \\
\hline 11 & $\mathrm{mt}-\mathrm{pt}$ & Pasar moneter (LM) & Endogen \\
\hline 12 & $\mathrm{q}_{\mathrm{t}-1}$ & Permintaan valuta asing satu periode sblmnya & Eksogen \\
\hline 13 & $\mathrm{q}_{\mathrm{t}+1}$ & Permintaan valuta asing satu periode kedepan & Eksogen \\
\hline 14 & $\left(\mathrm{i}_{\mathrm{t}-1-\pi_{\mathrm{t}-}}\right.$ & Suku bunga riel/suku bunga riel internasional & Eksogen \\
\hline 15 & $\mathrm{Sbi} /(\mathrm{fr}))$ & Suku bunga BI rate 3 bulan & \\
\hline 16 & $(\mathrm{yt}-\mathrm{yt} *)$ & Output gap & Endogen \\
\hline 17 & $\left(\pi_{\mathrm{t}-} \pi_{\left.\mathrm{t}^{*}\right)}\right.$ & inflasi target gap & Eksogen \\
\hline
\end{tabular}

\section{METODE}

Metode analisis disusun sejalan dengan kebutuhan model yang telah dibangun berdasarkan referensi teori yang tersedia. Model transmisi makro ekonomi yang telah diturunkan dari arrow scheme ke sistem persamaan struktural menunjukkan bahwa bentuk pemodelan adalah saling terkait satu sama lainnya, sehingga pilihan yang tersedia adalah melakukan pengembangan metode ekonometrik secara simultan sebagai upaya untuk menguji hubungan antar variabel makro ekonomi yang termuat dalam pemodelan.

Hasil analisis menunjukkan bahwa tidak seluruh spesifikasi yang direncanakan dalam perumusan model dapat diterjemahkan pada fenomena nyata perekonomian Indonesia, sehingga terdapat arah perubahan sejumnlah arrow scheme yang tidak sama persis sebagaimana dirumuskan pada bagan 1.2. Penyebab dari tidak terpenuhinya spesifikasi model adalah bahwa pengujian model ternyata tidak signifikan, sehingga terdapat sejumlah variable harus dilakukan drop-out untuk mendapatkan justifikasi model yang lebih layak dipercaya.

Pertama, adalah mengeluarkan variable nilai tukar dari persamaan IS, yang ternyata memiliki efek multi-collonearity pada variable sukui bunga riel. Kedua, tidak ditemukannya inflasi Philip Curve dalam perekonomian Indonesia. Ternyata inflasi 
yang terbentuk disebabkan oleh pengaruh tidak langsung dari output riel yang bergerak melaukan perubahan terhadap pasar moneter, serta perubahan pasar moneter melalui jumlah uang beredar kemudian mempengaruhi pergerakan inflasi. Ketiga, permintaan pasar valuta asing yang tidak menyertakan ekspektasi, di mana spesifikasi model tidak mendapat dukungan uji statistik secara memadai. Keempat, dikeluarkannya ekspektasi inflasi dari persamaan opened policy rule, karena searah dengan hal yang sama sebelumnya, yaitu tidak mendapatkan dukungan uji statistik yang diperlukan.

\section{Pengujian Kelayakan Data Time Series Kointegrasi}

Gujarati (2005), Enders (2004) dan Thomas (1997), merekomendasikan penggunaan uji kointegrasi Engle-Granger test untuk penelitian yang mempergunakan pemodelan atau hubungan fungsi, sehingga apabila terpenuhi kriteria di mana nilai $t$ atau memiliki negatif lebih besar, maka data time series dinyatakan terkointegrasi dan dapat dilanjutkan dengan penggunaan metode OLS. Untuk tujuan tersebut, perlu dilakukan pengujian kointegrasi pada tahap pertama, kemudian diteruskan dengan pengujian ECM pada tahap berikutnya.

Dinyatakan sebagai data time series yang stationer apabila data periode yang dikumpulkan dari waktu ke waktu merupakan rangkaian seri yang tidak terputus. Jika data time seres non stationer, maka informasi data hanya dapat dipergunakan dalam periode waktu pengamatan, sehingga tidak mungkin dapat dilakukan generalisasi dari estimasi data untuk periode waktu yang lain (Enders, 2004, Thomas, 1994). Berdasarkan Tabel 5.1 dapat dinyatakan bahwa pada tingkat signifikansi 1\%, diperoleh nilai ADF test calculated memiliki negatif lebih besar dari test critical value table DF, sehingga dapat dinyatakan kelima persamaan adalah terkointegrasi. Berdasarkan hasil uji kointegrasi pada Tabel 5.1, ternyata seluruh model terkointegrasi, sehingga dapat diteruskan dengan mempergunakan metode OLS dengan estimasi yang tidak menyesatkan.

Tabel 5.1 :

Hasil Uji Kointegrasi Metode Engel-Granger Test Model Makro dan Policy Rule

\begin{tabular}{|l|l|l|c|r|}
\hline $\begin{array}{l}\mathrm{N} \\
\mathrm{o}\end{array}$ & Asal Persamaan & Independent variable & $\begin{array}{c}\text { ADF } \\
\text { Test }\end{array}$ & Prob. \\
\hline 1 & Persamaan IS & resiscurve(-1) & $-12.5197 *)$ & 0.0000 \\
\hline 2 & Persamaan & resinfl(-1) & - & 0.0000 \\
\hline
\end{tabular}




\begin{tabular}{|l|l|l|r|r|}
\hline & INFLASI & & $\left.4.4752^{*}\right)$ & \\
\hline 3 & Persamaan LM & reslmcurve(-1) & $\left.-6.3902^{*}\right)$ & 0.0000 \\
\hline 4 & Persamaan Kurs & Resfecurve(-1) & $-4.2784 *)$ & 0.0000 \\
\hline 5 & $\begin{array}{l}\text { Persamaan Poliy } \\
\text { Rule }\end{array}$ & Resprule(-1) & $-3.8727 *)$ & 0.0001 \\
\hline
\end{tabular}

Test critical value : $1 \% \quad-2.634 \quad *)$

$$
\begin{array}{rrr}
5 \% & -1.951 & * *) \\
10 \% & -1.610 * * *)
\end{array}
$$

\section{Pengujian Model makro Dan Policy Rule Dengan ECM}

Berdasarkan Granger Representation Theorem, bahwa data yang telah terkointegrasi juga memiliki pola distribusi yang searah dengan hasil yanmg diperoleh pada Error Correction Mechanism (ECM). Hasil analisis ECM ternyata memperkuat kesimpulan yaitu bahwa data time series yang dipergunakan adalah stasioner. Tabel 5.2 menyajikan hasil analisis ECM.

Tabel 5.2:

Hasil Uji ECM Model Makro dan Policy Rule

\begin{tabular}{|l|l|l|c|c|}
\hline $\begin{array}{l}\mathrm{N} \\
\mathrm{o}\end{array}$ & Asal Persamaan & Independent variable & $\begin{array}{c}\text { ADF } \\
\text { Test }\end{array}$ & Prob. \\
\hline 1 & Persamaan IS & resiscurve(-1) & $\left.-.7 .957^{*}\right)$ & 0.0000 \\
\hline 2 & $\begin{array}{l}\text { Persamaan } \\
\text { INFLASI }\end{array}$ & resinfl(-1) & $\begin{array}{c}- \\
\left.5.8448^{*}\right)\end{array}$ & 0.0000 \\
\hline 3 & Persamaan LM & reslmcurve(-1) & $\left.-3.1072^{*}\right)$ & 0.0234 \\
\hline 4 & Persamaan Kurs & Resfecurve(-1) & $\left.-5.6553^{*}\right)$ & 0.0000 \\
\hline 5 & $\begin{array}{l}\text { Persamaan Poliy } \\
\text { Rule }\end{array}$ & Resprule(-1) & $-2.599 * *)$ & 0.0139 \\
\hline
\end{tabular}

Test critical value : $1 \% \quad-2.634 \quad *)$

$$
\begin{array}{rrr}
5 \% & -1.951 * *) \\
10 \% & -1.610 * * *)
\end{array}
$$

Berdasarkan criteria pengujian $1 \%$, ternyata seluruh persamaan memiliki negative lebih besar dari pada DF test critical value, kecuali persamaan policy rule yang signifikan pada criteria uji 5\%. Dengan hasil uji sebagaimana disajikan pada Tabel 5.2 maka dapat dinyatakan bahwa pengujian ECM telah mendukung hasil pengujian Engle-Granget test sebelumnya yaitu bahwa data time series adalah stasioner, sehingga dapat menghasilkan estimasi yang tidak menyesatkan.

\section{HASIL DAN PEMBAHASAN}


Hasil analisis kointegrasi dan ECM memberikan gambaran bahwa bahwa data time series ternyata pada kondisi stasioner yang telah terkointegrasi, sehingga tidak menghasilkan model regressi yang menyesatkan, sekaligus dapat dinyatakan bahwa hasil analisis ekonometrik yang mempergunakan metode OLS dapat diteruskan. Model ekonomi makro berskala kecil yang disusun pada penelitian ini sebagai model transmisi yang memuat hubungan antar variable sebagaimana telah dirumuskan melalui penelusuran teori, adalah merupakan rangkaian hubungan yang saling berkaitan antara satu persamaan dengan persamaan lainnya, sehingga dalam penyelesaian model transmisi tersebut memerlukan metode ekonometrik simultan. Penggunaan metode OLS secara parsial sangat tidak dimungkinkan, karena tidak diperhitungkan adanya error term yang dibawa oleh variable ekonomi makro bersangkutan ketika menjadi variabel independen pada sistem persamaan lainnya.

Berdasarkan pertimbangan tersebut maka penelitian ini memilih mempergunakan metode simultan 2SLS yaitu regressi dua tahap yang dilakukan dengan menguraikan penetapan reduced form sebagai metode yang menjembatani terbentuknya regressi OLS tahap kedua.Penggunaan reduced form merupakan prosedur yang lazim dilakukan untuk penaraan metode 2SLS. Cara mendapatkan reduced form adalah dengan menempatkan seluruh persamaan disebelah kanan adalah terdiri dari variable eksogen. Dengan demikian, untuk menurunkan reduced form dari persamaan structural, maka terlebih dahulu telah dilakukan pengelompokkan data sebagaimana telah disajikan pada Tabel 1.1, yaitu penetapan dengan jelas katagori variable eksogen dan endogen. Pada tahap berikutnya, dalam rangka mendapatkan model simultan, maka reduced form ditetapkan menjadi varabel instrumen yang pada gilirannya membentuk perubahan pada sejumlah variable endogen. Hasil estimasi dari proses penggunaan variable intrumen dikelompokkan sebagai OLS tahap kedua. Hasil analisis simultan untuk kelima persamaan disajikan pada Tabel 5.3.

Berdasarkan hasil analisis yang dimuat pada Tabel 5.3 dapat dinyatakan bahwa seluruh persamaan yang dihasilkan dari penggunaan data time series secara nyata mendukung spesifikasi modal. Sebagaimana tampak dari nilai statistik diatas 2, sekaligus menunjukkan bahwa parameter adalah signifikan berdasarkan tingkat kepercayaan 5\%, sehingga cukup memadai untuk dapat diangkat ke tingkat rekomendasi penelitian.

Hal tersebut karena perekonomian Indonesia memiliki karakter backward looking yaitu dicirikan oleh pola prilaku publik yang masih terikat kepada informasi 
masa lalu sebagai pijakan dalam melihat arah perekonomian di masa datang. Meskipun demikian, telah terdapat indikasi akan terbentuknya pemahaman publik tentang perlunya memanfaatkan informasi tahun berjalan sebagai bagian pertimbangan penting dalam melihat arah peregerakan perekonomian masa datang. Penemuan parameter sebesar 0.39 adalah estimasi terkait dengan karakter forward looking. Hal lain yang dapat digambarkan dari prilaku pasar barang (persamaan IS) adalah pengaruh perubahan suku bunga riel terhadap pergerakan output riel. Ternyata parameter suku bunga riel bertanda negatif, sehingga dapat diprediksi bahwa pergerakan suku bunga riel berlawanan arah dengan pergerakan output riel. Dengan demikian, apabila suku bunga riel ditingkatkan, maka akan berdampak pada penurunan output riel.

Dalam model ekonomi makro di mana pergerakan satu variable akan membawa dampak keterkaitan satu sama lainnya, maka pada model simultan yang telah didapatkan, perubahan suku bunga riel dan output riel berdampak pada pasar uang dan pasar nilai tukar. Hal ini karena kenaikan suku bunga riel memiliki dampak berlawanan arah dengan permintaan real balance, sehingga kenaikan suku bunga riel akan menurunkan permintaan riel balance. Pada periode berikutnya, penurunan output riel juga akan berdampak pada pasar moneter. Penurunan output riel sebagai akibat dari kenaikan suku bunga akan ditanggapi oleh pasar moneter dengan penurunan permintaan real balance, sehingga dengan demikian penurunan permintaan real balance diakibatkan oleh dua variable ekonomi makro lainnya, yaitu kenaikan suku bunga riel dan penurunan output riel.

Pada sisi lain, sehubungan dengan kenaikan suku bunga riel juga akan membawa dampak pada pasar valuta. Kenaikan suku bunga riel domestik akan berdampak pada apresiasi rupiah terhadap US \$, hal mana disebabkan oleh kenaikan suku bunga riel yang mengurangi permintaan real balance. Dengan demikian, penurunan jumlah uang beredar berdampak apresiatif rupiah terhadap US \$, dengan anggapan tidak terjadi perubahan pada suku bunga internasional, maka kenaikan suku bunga domestik pada giliran berikutnya berdampak capital inflow.

Tabel 5.3:

Hasil Analisis Simultan Model Makro dan Policy Rule

\begin{tabular}{|l|l|l|l|l|}
\hline $\mathrm{N}$ & Jenis & Nama Variabel & Parameter & Statistic t \\
\hline
\end{tabular}




\begin{tabular}{|c|c|c|c|c|}
\hline o & Persamaan & & & \\
\hline 1 & $\begin{array}{l}\text { yt } \\
\text { yt-1 } \\
\text { yt+1 } \\
\text { sbi-nfx }\end{array}$ & $\begin{array}{l}\text { Persamaan pasar barang IS } \\
\text { Lag satu periode seblmnya output } \\
\text { riel } \\
\text { Lead satu periode seblmnya } \\
\text { output riel } \\
\text { Suku bunga domestik riel }\end{array}$ & $\begin{array}{r}0.4933 \\
0.3936 \\
-0.0359\end{array}$ & $\begin{array}{r}2.7205 \\
2.1417 \\
-2.5497\end{array}$ \\
\hline 2 & $\begin{array}{l}\mathrm{nfx} \\
\mathrm{nfx}_{\mathrm{t}-1} \\
\mathrm{nfx}_{\mathrm{t}+1} \\
\mathrm{msx} \\
\text { kurs }\end{array}$ & $\begin{array}{l}\text { Persamaan inflasi } \\
\text { Lag satu periode inflasi yoy } \\
\text { Lead satu periode inflasi yoy } \\
\text { Jumlah uang beredar } \\
\text { Nilai tukar nominal (Rp/US \$D) }\end{array}$ & $\begin{array}{l}0.5205 \\
0.4151 \\
0.1894 \\
0.3168\end{array}$ & $\begin{array}{l}5.4378 \\
4.3513 \\
2.8534 \\
2.4122\end{array}$ \\
\hline 3 & $\begin{array}{l}\mathrm{m}_{\mathrm{t}}-\mathrm{p}_{\mathrm{t}} \\
\text { yt } \\
\text { sbi-nfx }\end{array}$ & $\begin{array}{l}\text { Persamaan pasar uang LM } \\
\text { Produk domestic bruto riel } \\
\text { Suku bunga riel domestik }\end{array}$ & $\begin{array}{r}6.1157 \\
-0.6207\end{array}$ & $\begin{array}{r}6.058 \\
-2.186\end{array}$ \\
\hline 4 & $\begin{array}{l}\text { Kurs } \\
\text { sb-nfx } \\
\text { fi }\end{array}$ & $\begin{array}{l}\text { Permintaan Pasar Valuta } \\
\text { Suku bunga riel domestik } \\
\text { Suku bunga internasional riel }\end{array}$ & $\begin{array}{l}-0.3324 \\
-1.3736\end{array}$ & $\begin{array}{l}-6.6406 \\
-4.2519\end{array}$ \\
\hline 5 & $\begin{array}{l}\text { SBI } \\
\text { gyy } \\
\text { gff } \\
\text { kurs }\end{array}$ & $\begin{array}{l}\text { Persamaan suku bunga BI Rate } \\
\text { Deviasi output riel } \\
\text { Deviasi inflasi target } \\
\text { Nilai tukar }\end{array}$ & $\begin{array}{r}1.2386 \\
0.5952 \\
-0.7077\end{array}$ & $\begin{array}{r}2.5231 \\
4.6901 \\
-3.9242\end{array}$ \\
\hline
\end{tabular}

Berbeda dengan spesifikasi model yang disusun penelitian ini, pembentukan inflasi tidak berhubungan langsung dengan pergerakan output riel, tetapi dampak dari pergerakan output riel pada pasar moneter akhirnya membentuk pergerakan inflasi. Hal yang perlu dicatat sehubungan dengan pergerakan inflasi, yaitu bahwa inflasi merupakan pencerminan stabilitas perekonomian nasional, sehinga menjadi sangat dekat dengan tugas Bank Sentral untuk mengendalikannya. Sehubungan dengan itu, bahwa ternyata karakter inflasi di Indonesia searah dengan karakter persamaan IS yang menggambarkan lebih menonjolnya ekspektasi backward looking dibandingkan 
dengan forward looking. Hal ini sekaligus mengindikasikan bahwa pengetahuan publik tentang arah pergerakan inflasi di masa datang lebih banyak ditentukan oleh informasi periode sebelumnya.

Hal mendasar lain yang berkaitan dengan persamaan inflasi yaitu bahwa, proses pembentukan inflasi tidak sejalan dengan pendekatan Philips Curve yang memandang inflasi terbentuk dari hubungan inflasi dengan output. Ternyata inflasi yang terbentuk merupakan mata rantai perubahan output riel ke pasar moneter, serta dari pasar moneter kemudian berproses mempengaruhi pergerakan inflasi. Berdasarkan persamaan inflasi didapatkan pola hubungan positif antara jumlah uang beredar (msx) dengan pergerakan inflasi. Hal yang juga searah adalah pengaruh perubahan nilai tukar terhadap pembentukan inflasi.

Dengan demikian dapat dinyatakan bahwa penurunan jumlah uang beredar sebagai akibat dari peningkatan suku bunga riel berdampak deflasi. Dengan demikian, tampak bahwa penurunan output berdampak pada penurunan inflasi atau dengan kata lain, telah terjadi trade-off dalam jangka pendek di mana penurunan inflasi mengakibatkan peningkatan pengangguran melalui penurunan output.

Perubahan pembentukan keseimbangan jangka pendek akan bergeser sejalan dengan terjadinya shocks termasuk aggregate demand shocks maupun yang bersumber dari aggregate supply shocks. Menyadari akan terjadinya pergerakan tingkat keseimbangan jangka pendek tersebut, maka Bank Sentral dapat memanfaatkan intrumen BI Rate sebagai policy variable untuk mencapai target stabilitas ekonomi dengan pertumbuhan ekonomi yang cukup tinggi. Opened policy rule adalah rule yang bersifat endogen, di mana besaran suku bunga BI Rate tidak ditentukan secara arbitrer, tetapi dilakukan atas sejumlah kondisi yang diinginkan. Dengan demikian, target kebijakan moneter yang diinginkan Bank Sentral dapat dilakukan dengan pilihan pembobotan pada output gap, deviasi target inflasi serta nilai tukar. Pembobotan yang berbeda terhadap ketiga variable ekonomi makro tersebut akan menghasilkan besaran BI Rate yang berbeda, sehingga juga akan akan berdampak pada sasaran akhir dari kebijakan pembobotan tersebut.

Melalui sejumlah langkah simulasi dengan penerapan pembobitan pada opened policy rule, diharapkan dapat melengkapi jawaban dari penelitian ini yaitu bahwa openeded policy rule merupakan model yang realistik untuk dipergunakan dalam pengendalian ekonomi makro yaitu menuju sasaran akhir stabilitas ekonomi jangka pendek. 


\section{Simulasi Policy Rule dan Model Makro Ekonomi}

Simulasi dilakukan untuk mendapatkan gambaran peranan dari BI rate sebagai instrumen moneter dalam menggerakkan keseimbangan ekonomi makro serta efektivitas dari suku bunga BI rate dimaksud sebagai instrumen dalam mencapai sasaran akhir kebijakan moneter yaitu stabilitas perekonomian nasional, yang memuat terkendalinya inflasi dan pada saat bersamaan dapat dicapai pertumbuhan ekonomi yang cukup memadai.

Penelitian ini melakukan simulasi diluar data sampel pada dua tahapan. Tahap pertama, adalah simulasi dilakukan untuk openeded policy rule. Simulasi dilakukan dengan memberikan pembobotan (magnitudes) pada output gap, inflation target gap serta variable nilai tukar. Pembobotan dilakukan dengan rincian sebagai berikut.

Tabel 5.4:

Simulasi Pembobotan Variabel Independent pada Openeded Policy Rule

\begin{tabular}{|l|l|l|l|}
\hline No. & Variabel Output gap & $\begin{array}{l}\text { Variabel Inffasli } \\
\text { target }\end{array}$ & Variabel nilai tukar \\
\hline 1 & Dinaikkan 75\% & Diturunkan 25\% & Tetap \\
\hline 2 & Diturunkan 75\% & Dinaikkan 75\% & Tetap \\
\hline 3 & Ditetapkan & Ditetapkan & Depresiasi 10\% \\
\hline 4 & Ditetapkan & Ditetapkan & Apresiasi 10\% \\
\hline
\end{tabular}

Simulasi pada fungsi reaksi opened policy rule dimaksudkan untuk mendapatkan hasil akhir besaran BI rate, sebagai akibat dari simulasi yang diterapkan. Berdasarkan 4 simulasi diharapkan didapatkan besaran BI rate yang berbeda, sehingga dengan demikian akan didapatkan pemahaman secara empirik pola kebijakan pembobotan serta hasil akhir yang diharapkan dari simulasi pembobotan tersebut.

Simulasi pembobotan dengan menaikkan output gap sebesar 75\% (simulasi 1), ternyata memberi dampak pada perubahan besaran suku bunga BI rate yang berbeda dengan nilai aktualnya. Grafik 1.6 menunjukkan hasil simulasi dimaksud. Dengan keterbatasan media yang dipergunakan, tulisan ini hanya membahas dan memberikan fokus kepada kebijakan simulasi menaikkan suku bunga, serta dampaknya terhadap sistem keseimbangan secara simultan. Simulasi penurunan BI rate tidak dibahas pada penelitian ini, sejauh ini diperkirakan akan memiliki dampak pada arah perubahan 
perluasan ruang gerak pertumbuhan ekonomi dengan akibat meningkatnya pertumbuhan inflasi.

Pertama adalah simulasi dengan menaikkan output gap $75 \%$, ternyata mendapatkan BI rate yang menaik lebih tinggi dari BI rate actual. Dengan ini dapat diperoleh bukti secara empiric bahwa kebijakan menaikkan pembobotan output gap akan menyebabkan peningiatan besaran suku bunga $\mathrm{BI}$ rate.

\section{Grafik 1.6 : Simulasi 1:}

Pembobotan output gap $75 \%$, Inflasi target $-25 \%$, nilai tukar tetap

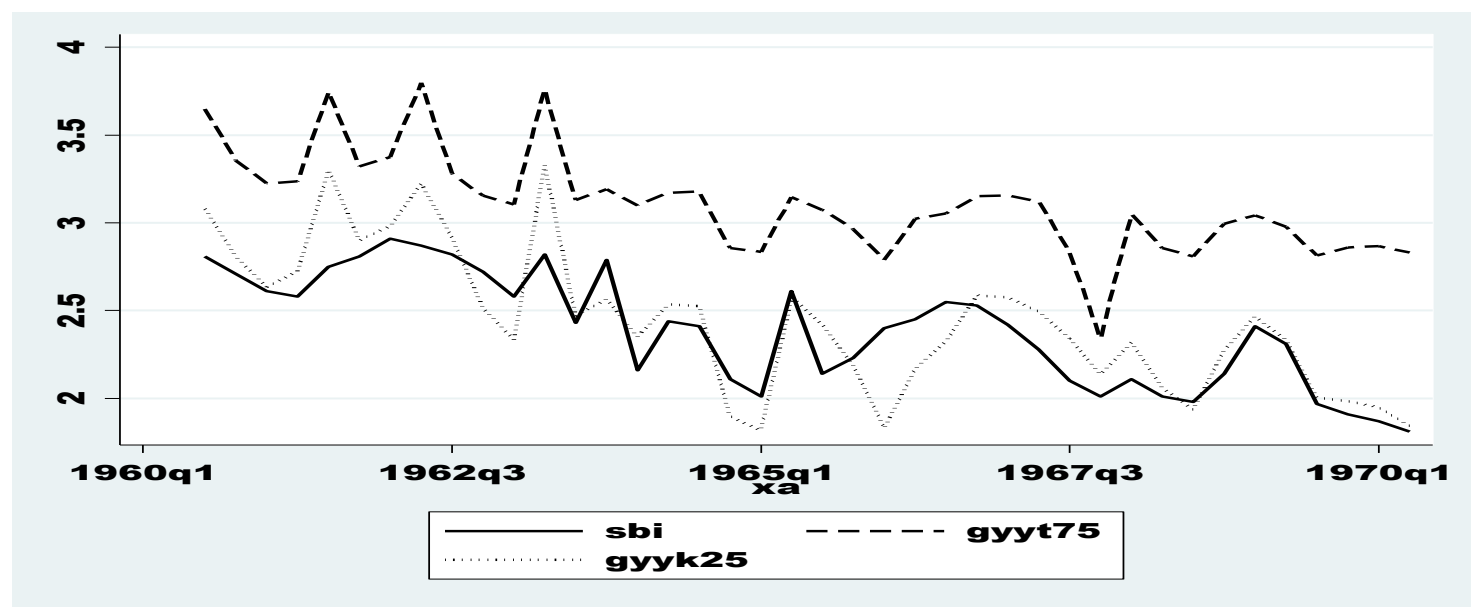

Sebaliknya, dengan menurunkan pembobitan output gap sebesar $-25 \%$, dan menaikkan pembobotan gap inflasi dari kisarannya sebesar $75 \%$, ternyata menghasilkan sebaran BI rate yang menyebar disekitar nilai actual BI rate. Dengan hasil ini maka dapat dinyatakan bahwa selama ini opened policy rule lebih dekat dengan kebijakan pembobotan target inflasi dibandingkan dengan kebijakan pemboboitan pada output gap.

Grafik 1.7 :

Simulasi Pembobotan pada nilai tukar 


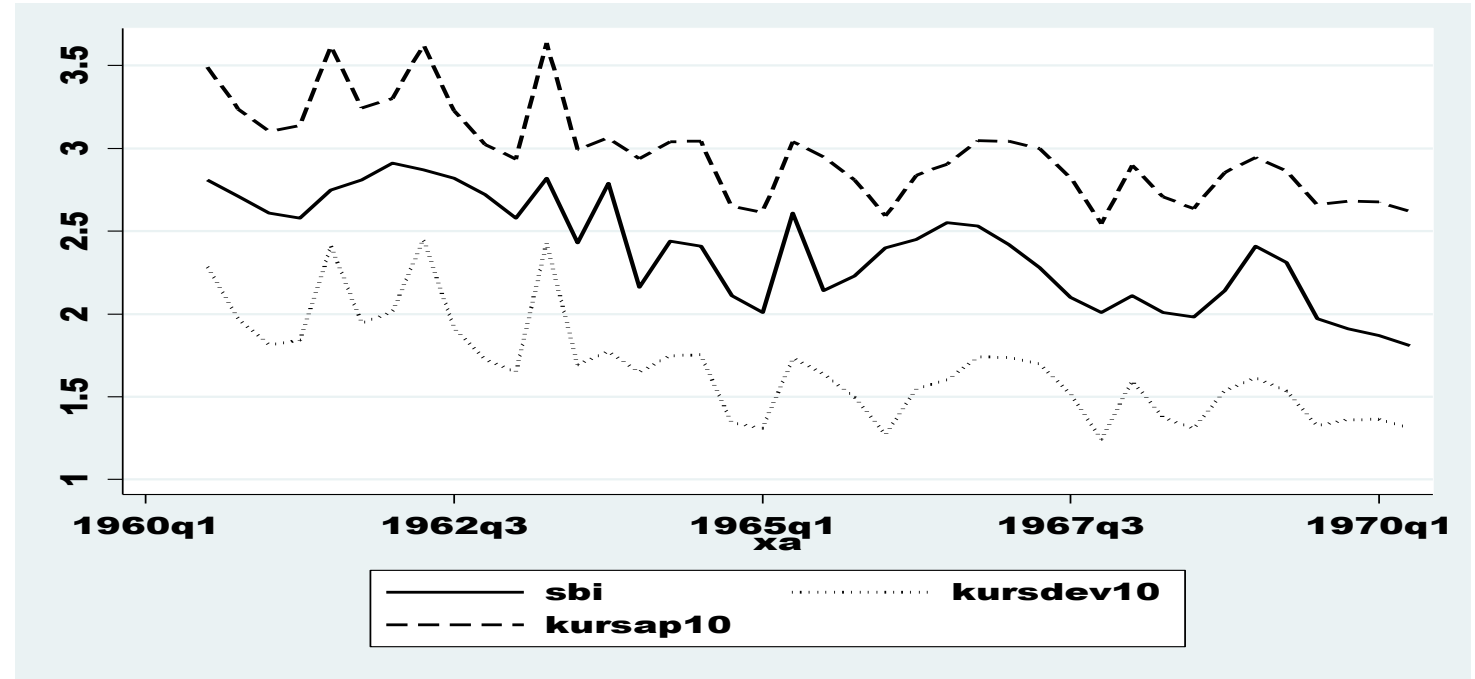

Pembobotan nilai tukar dilakukan dengan 2 cara, yaitu depresiasi sebesar $10 \%$ dan apresiasi nilai tukar sebesar 10\%, yang ternyata menghasilkan 2 pergerakan SBI rate yang berbeda. Pada simulasi dengan mendepresiasikan rupiah sebesar $10 \%$, dengan anggapan tidak ada pembobotan pada output gap dan inflasi target, ternyata menghasilkan seberan nilai BI rate dibawah nilai BI rate actual. Hal ini memberikan bukti bahwa apabila opened policy rule dimaksudkan dalam rangka mendorong pertumbuhan ekspor, maka dapat dilakukan dengan menurunkan BI rate dalam kisaran jauh di bawah BI rate actual yang berlaku saat ini.

Dapat disimpulkan bahwa dalam strategi pembobotan menghasilkan dua besaran suku bunga yaitu meningkat lebih besar dari kisaran BI rate actual atau berada dibawah kisaran BI rate actual. Dengan demikian dapat dinyatakan bahwa terdapat kemungkinan penggunaan kebijakan pembobotan menaikkan output gap yang meningkatkan kisaran suku bunga, atau mensimulasikan kenaikan nilai tukar rupiah (simulasi devaluasi) yang berdampak pada penurunan kisaran BI rate dari nilai aktualnya. Dalam rangka memahami bagaimana pengaruh perubahan BI rate terhadap sistem keseimbangan makro ekonomi, maka simulasi berikutnya akan mempergunakan scenario kenaikan suku bunga Bi rate serta dampaknya terhadap sistem keseimbangan makro ekonomi yang meliputi pasar barang (IS), pasar moneter (LM), pasar nilai tukar (FE) serta pergerakan inflasi. Pertama, dengan anggapan Bank Sentral mengendalikan inflasi lebih rendah dengan mengabaikan target makro ekonomi lainnya, maka Bank Sentral akan menaikkan pembobotan ouput gap, serta berakibat pada peningkatan suku bunga BI rate. 
Grafik 1.8 : Pertumbuhan Output actual dan Simulasi Kenaikan BI Rate

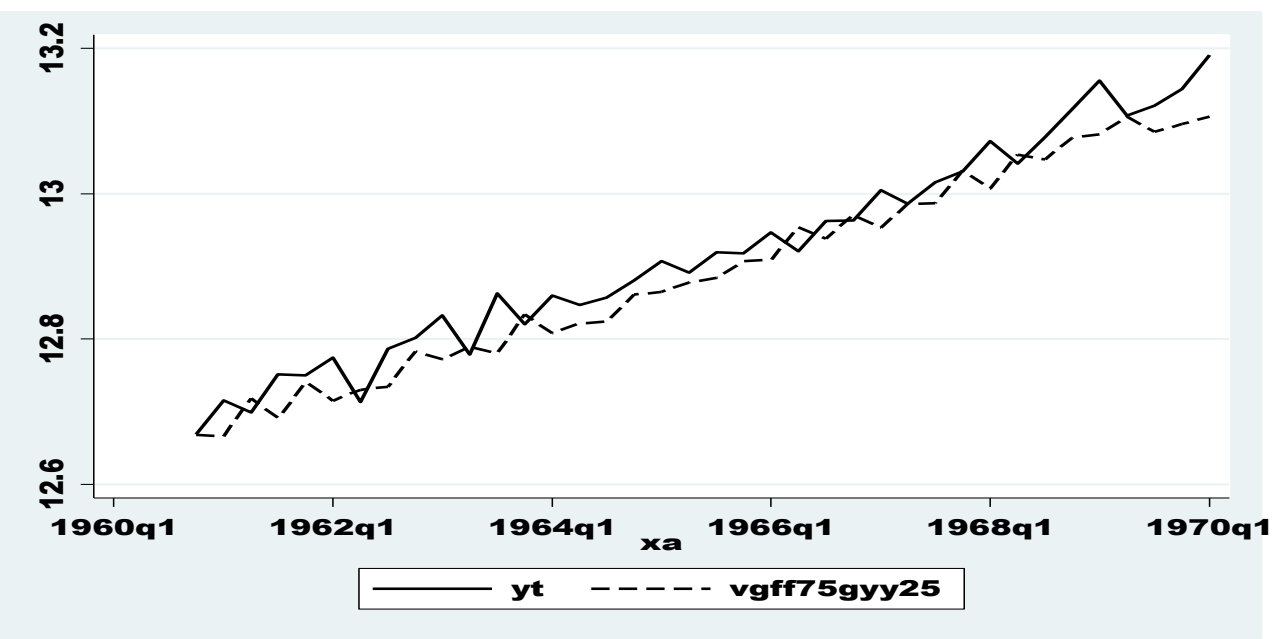

Kenaikan BI rate telah berdampak pada penurunan output riel, sebagai akibat dari peningkatan biaya produksi dan investasi menyebabkan produksi mengalami penurunan. Pada saat bersamaan, penurunan output juga mengekang pertumbuhan permintaan real balance. Kenaikan BI rate juga berdampak secara langsung pada pasar moneter. Grafik 1.9 menyajikan dampak penurunan output dan kenaikan BI rate di pasar moneter. Penurunan permintaan transaksi juga pada gilirannya berdampak pada pergerakan inflasi. bahwa dengan penurunan permintaan real balance menyebabkan menurunnya jumlah uang beredar, sehingga berdampak menurunkan pergerakan inflasi.

Grafik 1.9 : Permintaan real balance actual dan hasil simulasi kenaikan BI rate.

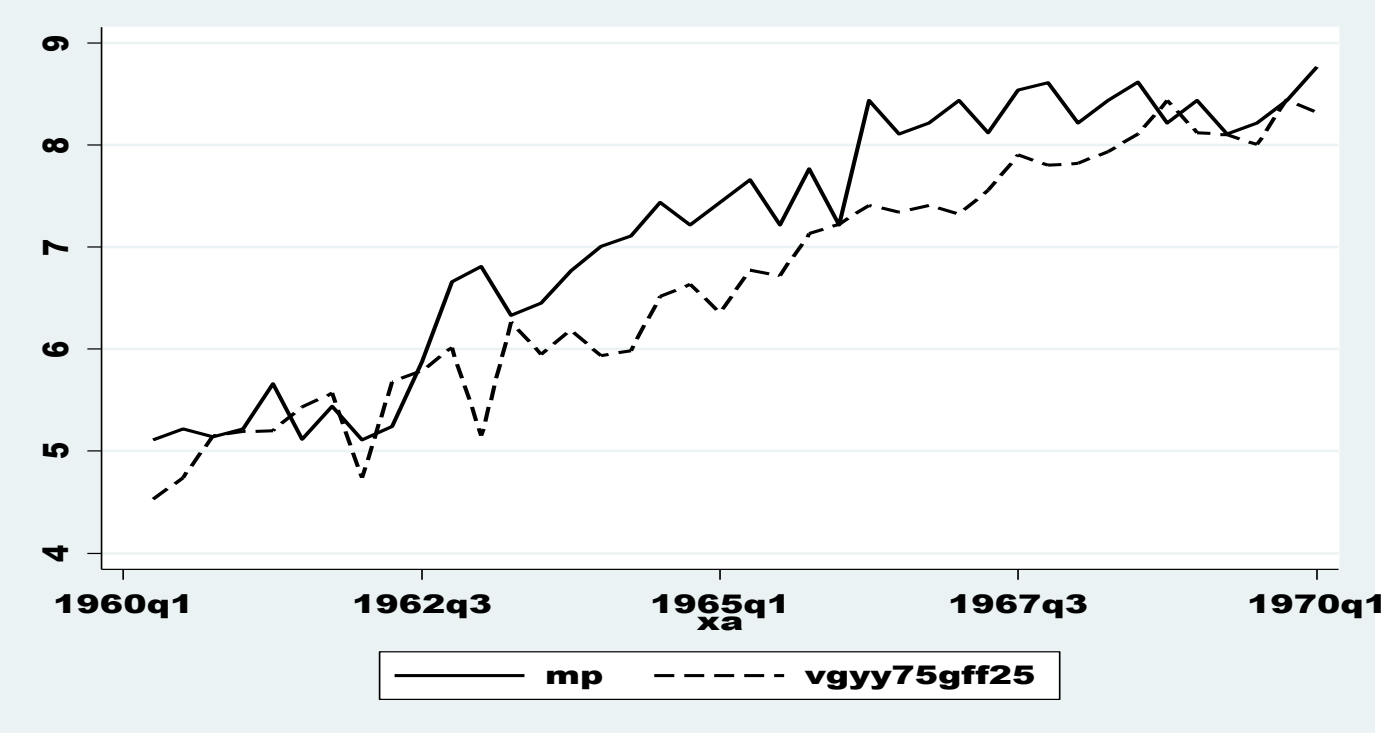


Pada sisi lain, kenaikan BI rate juga berdampak pada pasar valuta. Ternyata kenaikan BI rate telah berdampak apresiasi pada nilai tukar rupiah. Hal ini sejalan dengan penurunan jumlah uang beredar yang mengakibatkan mata uang rupiah menjadi lebih langka.

Grafik 1.10:

Permintaan real balance actual dan hasil simulasi kenaikan BI rate.

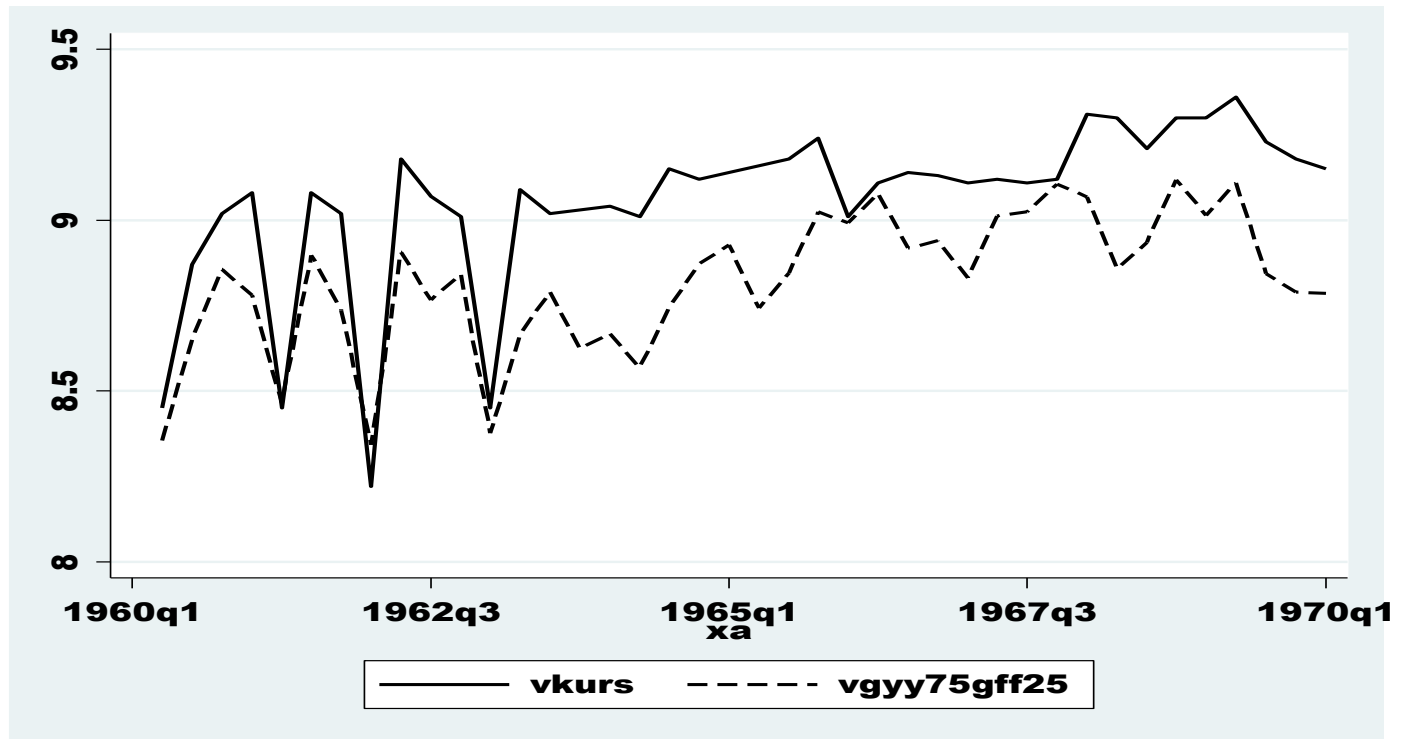

Penurunan jumlah uang beredar serta apresiasi nilai tukar pada gilirannya member dampak terhadap pergerakan inflasi. Grafik 1.10 menyajikan pola hubungan inflasi yoy actual dengan simulasi perubahan jumlah uang beredar dan apresiasi nilai tukar.

Grafik 1.11 : Permintaan real balance actual dan hasil simulasi kenaikan BI rate. 


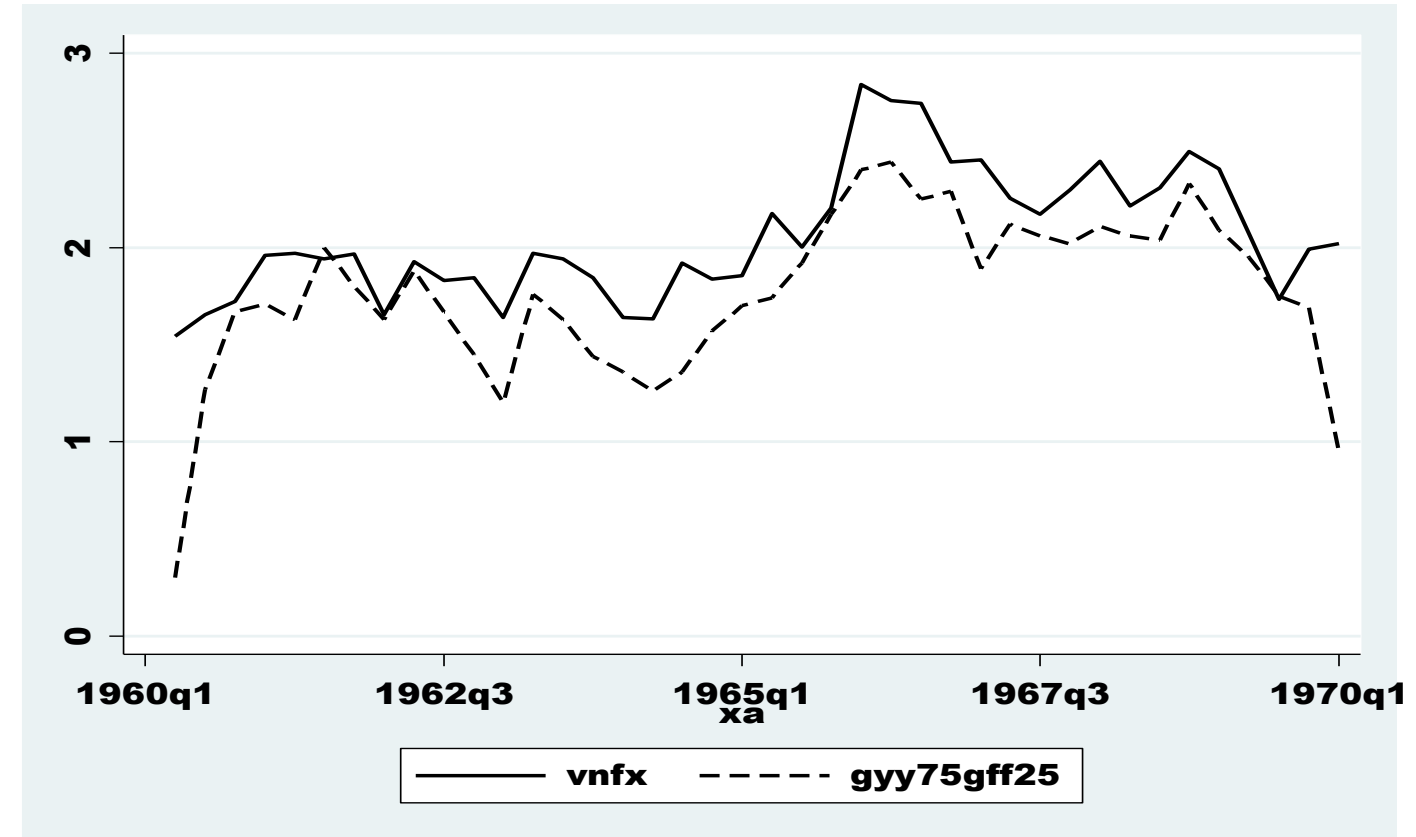

Ternyata hasil simulasi kenaikan BI rate menunjukkan arah penurunan pertumbuhan inflasi yaitu dimana nilai aktual BI rate berada di atas garis simulasi. Dengan demikian, tampak bahwa pilihan untuk menurunkan pertumbuhan inflasi dapat dilakukan dengan memberikan bobot lebih besar pada output gap. Sebaliknya, melonggarkan pertumbuhan inflasi akan bermakna sebaliknya, yaitu terciptanya ruang gerak yang lebih besar pada pertumbuhan ekonomi dapat dilakukan dengan menurunkan suku bunga BI rate dengan akibat peningkatan pada pertumbuhan inflasi. Menggandengkan secara bersama antara pertumbuhan ekonomi dengan melonggarkan inflasi pada tingkatan di mana tetap tercapai stabilitas ekonomi adalah pilihan yang mungkin dapat dilakukan Bank Indonesia dalam penataan ekonomi nasional ke depan.

\section{Kesimpulan dan Saran}

Model mempergunakan pendekatan OLS simultan, sehingga dipandang perlu untuk melihat kondisi data times series agar sejalan dengan kriteria penggunaan OLS. Pengujian dengan prosedur Engle-Granger dan Metode ECM, keduanya menunjukkan signal statistik yang searah yaitu, bahwa data time series memiliki karakter terkointegrasi serta nilai negatif $\mathrm{t}$ statistik yang lebih besar dari DF test. Dengan demikian data time series telah memenuhi kriteria OLS. Spesifikasi model yang disusun berdasarkan pendekatan teoritik ternyata tidak seluruhnya dapat mencapai sasarannya. Inflasi yang diperkirakan mengikuti mekanisme Philip Curve termyata 
tidak terbukti melalui dukungan uji statistik. Ternyata output riel memiliki hubungan tidak langsung dengan inflasi yaitu dorongan perubahan inflasi yang disebabkan oleh perubahan jumlah uang beredar, serta perubahan jumlah uang beredar yang didorong oleh perubahan output riel.

Perekonomian Indonesia masih memiliki karakter backward looking, yaitu jenis ekspektasi yang mewakili pola pengambilan keputusan publik berdasarkan informasi dari periode sebelumnya. Meskipun tampak juga bahwa indikasi ke arah perubahan ekspktasi forward looking terdeteksi cukup kuat. Estimasi persamaan IS memberikan gambaran yang fundamental terkait dengan ekspektasi publik yang juga akan menjadi penggerak dinamika agregate demand di masa depan. Secara garis besar, model simultan telah mendukung sebagian besar spesifikasi model, sehingga kelima persamaan kayak dipergunakan sebagai acuan rekomendasi dan diteruskan ke langkah penelusuran efektivitas kebijakan moneter melalui pengembangan simulasi. Simulasi yang dilakukan pada openeded policy rule menunjukkan bahwa pembobotan pada output gap yang lebih besar dari kondisi aktualnya menyebabkan peningkatan suku bunga BI rate dari nilai aktualnya. Sebaliknya, dengan memberikan pembobotan terhadap inflasi target justru menunjukkan besaran BI rate berada pada kisaran BI rate aktualnya.

Simulasi lanjutan dengan menempatkan BI rate sebagai policy variable yang akan mendorong terbentuknya keseimbangan makro ekonomi menunjukkan bahwa simulasi kenaikan BI rate telah menurunkan output riel, serta akhirnya berdampak pada penurunan permintraan real balance. Pada sisi lain, kenaikan suku bunga telah mendorong capital inflow, yang berakibat pada apresiasi mata uang rupiah. Dampak pasar moneter dan pasar keuangan internasional ini akhirnya berpengaruh pada penurunan pertumbuhan inflasi. Dengan demikian, penelitian ini secara simultan menemukan masih bekerjanya trade-off jangka pendek antara inflasi dan penurunan output (peningkatan pengangguran).

\section{Saran}

Penelitian ini perlu ditekankan pada upaya penggalian data dengan pendekatan micro-foundation untuk menyingkap lebih detail aspek produksi dan struktur pasar, sehingga didapatkan informasi secara lebih substantial terkait dengan regiditas sektor produksi serta aspek produksi dalam memberikan kontribusi pada pergerakan inflasi. 


\section{DAFTAR PUSTAKA}

Abel, Andrew B and Bernanke, Ben S (2005), Macroeconomics, Pearson AddisonWesley. USA.

Aulia Pohan (2008), Kerangka Kebijakan Moneter \& Implementasinya di Indonesia. Raja Grafindo Persada, Jakarta.

Arreaza, Adriana, Blanco Enid and Dorta, Miguel (2003), A Small Scale Macroeconomic Model For Venezuela. Banco Central de Venezuela.

Batini, Nicoletta and Haldane, Andrew G (1998), Forward Looking Rules For Monetary Policy. Bank of England. Available at sciendirect.com

Bernanke, Ben S and Reinhart, Vincent (2004), Conducting Monetary Policy at Very Low Short-Term Interest Rates. American Economic Review.

Cavoly, Tony and Rajan, Ramkhishen S (2005), Inflation Targeting and Monetary Policy Rules For Small and Opened Developing Economies: Simple Analytics with Application to Thailand. Univ. of Adelaide.

Bogdanski, Joe, Alexdandro A. Tombini and Sergio Werlang (2001), Implementing I nflation Tarageting In Brazil. Central Bank of Brazil. Available at

Dornbusch, Rudiger, and Fischer, Stanley (1976), Expectations and Exchange Rates Dynamics. Journal of Political Economy.

Enders, Walter. 2004. Applied Econometric Time Series, Joghn Wiley \& Son.

Greene, William,. 2003. Econometric Analysis. Prentice-Hall Inc.

Gujarati, Damodar, 2005. Basic Econometrics. Fourth Ed. McGraw-Hill Book. Kogakusha. Japan

Halim Alamsyah, Charles Joseph, Juda Agung and Doddy Zuverdy (2001), Towards Implementation of Inflation targeting In Indonesia. Bulletin of Indonesian Economic Studies, Vol 37, No. 3.

Hall, Robert E and Liebermanm Marc (2006), Macroeconomics, Principles and Applications. Thompce (2005), Exchange Rates and son, Shouthwestern. USA.

Hodrick, Robert J and Prescott, Edward C (1997), Postwar U.S. Business Cycles. An Empirical Investigation. Journal of Money, Credit and Banking.

MacNelis, Paul D (1999), Monetary Policy, The Role of Learning and Inflation targeting: Implications for Bank Indonesia. Direktirat Riset Bank Indonesia. Jakarta.

Mankiw, Gregory N (2002), Macroeconomics. McGraw-Hill Book Company. USA. 
Pindyck Robert and Rubenfeld. 1981. Econometric Model and Economic Forecast. McGraw Hill Book Kogakusha.

Svensson, Lars O (1996) Inflation Forecasting targeting: Implementing and Monitoring Inflation Targets..Princeton Univ. and NBER.

Tanuwidjaja, Enrico and Choy, Keen Meng (2006), Central Bank Credibility and Monetary Policy In Indonesia. Journal of Policy Modeling.

Taylor, John B (1999), The Monetary Transmission Mechanism and The Evaluation of Monetary Policy Rules. Stanford Univ. Available at SSRN.Com

Theil, Henry, 1987, Principle of Econometrics. Prentice-Hall. USA.

Thomas, L.R 2003. Modern Econometric. Addison-Wesley. USA.

Woodford, Michael (2001), The Taylor Rule and Optimal Monetary Policy. American Economic Review. 